\title{
Dynorphin Opioids Present in Dentate Granule Cells May Function as Retrograde Inhibitory Neurotransmitters
}

\author{
Carrie T. Drake, ${ }^{1}$ Gregory W. Terman, ${ }^{1,2}$ Michele L. Simmons, ${ }^{1}$ Teresa A. Milner, ${ }^{5}$ Dennis D. Kunkel, ${ }^{3}$ Philip A. \\ Schwartzkroin, ${ }^{3,4}$ and Charles Chavkin ${ }^{1}$ \\ Departments of ${ }^{1}$ Pharmacology, ${ }^{2}$ Anesthesiology, ${ }^{3}$ Neurological Surgery, and ${ }^{4}$ Physiology \& Biophysics, University of \\ Washington, Seattle, Washington 98195 and ${ }^{5}$ Department of Neurology and Neuroscience, Cornell University Medical \\ College, New York, New York 10021
}

The granule cell population response to perforant path stimulation decreased significantly within seconds following release of endogenous dynorphin from dentate granule cells. The depression was blocked by the opioid receptor antagonists naloxone and norbinaltorphimine, suggesting that the effect was mediated by dynorphin activation of $\kappa_{1}$ type opioid receptors. Pharmacological application of dynorphin $B$ in the molecular layer was effective at reducing excitatory synaptic transmission from the perforant path, but application in the hilus had no significant effect. These results suggest that endogenous dynorphin peptides may be released from a local source within the dentate molecular layer. By light microscopy, dynorphin-like immunoreactivity (dynorphin-LI) was primarily found in granule cell axons in the hilus and stratum lucidum with only a few scattered fibers evident in the molecular layer. At the extreme ventral pole of the hippocampus, a diffuse band of varicose processes was also seen in the molecular layer, but this band was not present in more dorsal sections similar to those used for the electrophysiological studies. Electron microscopic analysis of the molecular layer midway along the septotemporal axis revealed that dynorphin-LI was present in dense-core vesicles in both spiny dendrites and unmyelinated axons with the majority $(74 \%)$ of the dynorphin-LI-containing densecore vesicles found in dendrites. Neuronal processes containing dynorphin-LI were observed throughout the molecular layer. The results suggest that dynorphin release from granule cell processes in the molecular layer regulates excitatory inputs entering the hippocampus from cerebral cortex, thus potentially counteracting such excitation-induced phenomena as epileptogenesis or long-term potentiation.

IKey words: hippocampus, electron microscopy, light microscopy, endogenous opioids, dendritic transmitter release, peptide release]

Received Oct. 20, 1993; accepted Dec. 9, 1993.

This work was supported by grants from the USPHS: DA04123 (C.C.), NS18895 (P.A.S.), HL18974, DA08259 (T.A.M.), a PMA predoctoral fellowship (C.T.D.), and the Foundation for Anesthesia Education and Research (G.W.T.). We thank Paul Schwartz, Janet Clardy, and Oliver Kurucz for assistance, and John Wagner, Joseph Pierce, and James Schenk for helpful discussion.

Correspondence should be addressed to Dr. Charles Chavkin, Department of Pharmacology, SJ-30, University of Washington, Seattle, WA 98195.

Copyright (C) 1994 Society for Neuroscience $0270-6474 / 94 / 143736-15 \$ 05.00 / 0$
Understanding how neuropeptides function as neurotransmitters has been an elusive goal. We have focused on the physiological properties of the hippocampal opioid peptides, which are thought to be important modulators of excitability and may play a rolc in processes associated with both learning and memory (McDaniel et al., 1990) and epileptogenesis (Tortella et al., 1986; Hong et al., 1993). The dynorphin opioids are a family of more than five structurally related peptides that are synthesized from a common precursor (Kakidani et al., 1982) and coordinately released in hippocampus (Chavkin et al., 1985). All are potent agonists at the $\kappa_{1}$ type opioid receptor (Chavkin et al., 1982; James et al., 1984; Nock et al., 1990). Previous studies suggest that the dynorphin opioids regulate synaptic transmission in the dentate gyrus molecular layer of guinea pigs by activation of $\kappa_{1}$ receptors (Wagner et al., 1992). Application of $\kappa$ receptor-selective agonists decreases excitatory transmission from perforant path terminals in the molecular layer to the dentate granule cells and blocks induction of long-term potentiation at these synapses (Wagner et al., 1993). Furthermore, the release of endogenous dynorphins by stimulation parameters previously established (Wagner et al., 1991) similarly attenuates excitatory synaptic transmission and long-term potentiation in the molecular layer (Wagner et al., 1993). Similar opioid control of excitatory transmission has been identified in granule cell axon terminals in the CA3 region of hippocampus (Derrick et al., 1991; Weisskopf et al., 1993).

The guinea pig dentate gyrus contains both the prodynorphinderived opioid peptides (McLean et al., 1987) and their highaffinity binding sites, the $\kappa_{1}$ opioid receptors (Nock et al., 1988, 1990; Zukin et al., 1988). Whereas dynorphins are located primarily in the axons of granule cells coursing through the hilus to terminate in stratum lucidum of CA3 (McLean et al., 1987), $\kappa_{1}$ receptors are found primarily in the dentate molecular layer (Zukin et al., 1988; Wagner et al., 1991). This ligand/receptor mismatch has been observed for several subtypes of opioids and their receptors, and has led to the suggestion that opioids may diffuse in a neurohumoral fashion hundreds of micrometers to their target sites (McLean et al., 1987).

Perhaps the $\kappa$-mediated inhibitory effects of released dynorphins shown previously (Wagner et al., 1993) occurred as a result of dynorphin diffusing from hilar release sites to $\kappa$ receptors in the molecular layer. Alternatively, extensive diffusion may not be needed to explain the physiological actions if there is an additional source of dynorphin within the molecular layer, near high-affinity $к$ receptors. If dynorphin is indeed locally available, 
then two things would be predicted: (1) that the onset of endogenous dynorphin-dependent synaptic depression would be fast, and (2) that a high-resolution immunocytochemical investigation of the molecular layer would reveal dynorphin storage sites in the molecular layer of the dentate gyrus.

The experiments in this study were designed to address both physiological and anatomical aspects of the hypothesis that dynorphin is released within the molecular layer of the dentate gyrus. We characterized the onset of endogenous dynorphin action following release and examined the dynorphin distribution in the molecular layer at the light and electron microscopic levels. In the anatomical studies, we examined not only the localization of immunoreactivity to dynorphin $A_{1-8}$ and dynorphin $B_{1-13}$, but also the distribution of two other prodynorphin-derived peptides expected to overlap dynorphin staining. These were leu-enkephalin, a pentapeptide contained within dynorphin, and leumorphin (also called dynorphin $\mathrm{B}_{1-29}$ ), a C-terminally extended form of dynorphin that is biologically active and present in the hippocampi of several species (Neal and Neuman, 1989) but that has not yet been described in guinea pig.

\section{Materials and Methods}

\section{Electrophysiology,}

Hippocampal slices $(500 \mu \mathrm{m})$ were prepared from 175-250 gm adult male Hartley guinea pigs (Simonsen Labs, Gilroy, CA) as described previously (Wagner et al., 1992). All slices were cut in the horizontal plane using a Campden vibrotome. Slices with transverse morphology (Fig. $1 \mathrm{~A}$ ) were submerged in a $34^{\circ} \mathrm{C}$ chamber and superfused with Krebsbicarbonate buffer ( $\mathrm{pH} 7.4$ ) containing (mM) NaCl (125), $\mathrm{KCl}(3), \mathrm{CaCl}_{2}$ (4), $\mathrm{MgCl}_{2}$ (4), $\mathrm{NaH}_{2} \mathrm{PO}_{4}$ (1.25), $\mathrm{NaHCO}_{3}(26)$, and glucose (10), and saturated with $95 \% \mathrm{O}, 5 \% \mathrm{CO}$, . Bicuculline $(10 \mu \mathrm{M})$ was bath-applied to the slices to block $\mathrm{GABA}_{\mathrm{A}}$ receptors in order to study primarily excitatory responses.

Dentate granule cell population or field EPSP responses were evoked by stimulating with a concentric bipolar electrode $(100 \mu \mathrm{m}$ tip; SNE 100 , Kopf Instruments) in the outer molecular layer at the apex of the dentate gyrus. Axons of the perforant path originating from cntorhinal cortical cells enter the dentate in this region and synapse onto granule cell dendrites (Ramon y Cajal, 1911; Lorente de No, 1934; Laatsch and Cowan, 1966; Hjorth-Simonen, 1972). The stimulation pulse consisted of single square waves $(25-300 \mu \mathrm{A})$ of $0.3 \mathrm{msec}$ duration. Extracellular recording was performed using glass pipettes filled with $3 \mathrm{~m} \mathrm{NaCl}$. Three different extracellular measures of granule cell excitability were used (population spike amplitude, field EPSP amplitudes, and field EPSP slopes), and all three showed the same sensitivity to exogenous and endogenous dynorphin application.

In experiments investigating responses to endogenous dynorphin, recording electrodes were placed in the granule cell layer of the exposed blade of the dentate gyrus. The "exposed blade" refers to the half of the dentate gyrus that is adjacent to the ventricle in the intact brain. The amplitude of the granule cell population spike was measurcd (sce Fig. $1 A$ ) using a digitizing oscilloscope (5D10 Tektronix, Beaverton, OR). High-frequency stimulation (HFS) in the hilus was given using a second bipolar stimulating electrode and consisted of six trains (each 1 sec long, $50 \mathrm{~Hz})$ of pulses $(0.3 \mathrm{msec}, 300 \mu \mathrm{A})$ delivered every other second for $11 \mathrm{sec}$. The placement of stimulating and recording electrodes is shown in Figure $1 \mathrm{~A}$. In each slice, a stimulus-response curve was constructed for perforant path evoked granule cell population spikes. The stimulus required to evoke a half-maximal response $\left(S_{1,}\right)$ was calculated and utilized in subsequent testing. Following at least $10 \mathrm{~min}$ of recording to establish a stable baseline $S_{1 / 2}$, hilar HFS was given. Perforant path evoked population spike responses were then recorded every $10 \mathrm{sec}$ for $2 \mathrm{~min}$, then every $30 \mathrm{sec}$ up to $5 \mathrm{~min}$, and then every minute for the next $15 \mathrm{~min}$. In half of the slices $100 \mathrm{~nm}$ norbinaltorphimine (NBNI) was added to the perfusate $10 \mathrm{~min}$ after the hilar high-frequency stimulation. Twenty minutes after the initial stimulation all slices received a second hilar high-frequency stimulation and the effects on evoked population responses were measured as before. Statistical analysis of drug effects was done by two-way ANOVA with one repeated measure and Neuman-Keuls tests for post hoc comparisons. $p<0.05$ was selected to represent a significant difference.

In experiments involving exogenously applied dynorphin B, the slices were cut through the granule cell layer and hilus (see Fig. $2 C$. inset) to isolate the molecular layer of the exposed blade from excitatory inputs through the hilus previously described (Scharfman et al., 1990). Field EPSPs were measured using an extracellular recording electrode placed in the outer third of the molecular layer, where the perforant path axons terminate on granule cell dendrites, and evoked by a stimulating electrode placed in the outer molecular layer on the opposite side of the cut. In each slice, dynorphin B (100 $\mu \mathrm{M}$, in Krebs-bicarbonate buffer) was applied separately to the subgranular zone of the hilus and to the outer half of the molecular layer through a glass pipette connected to a Picospritzer (General Valve Co., Fairfield, NJ). The size of the droplet applied was approximately $0.1-1 \mathrm{nl}$ (as measured in the recording chamber above the brain slice), which would deliver 10-100 fmol per pulse. This amount is comparable to the total releasable pool of dynorphin $B$ present: the rat hippocampus contains $460 \mathrm{fmol}$ of dynorphin B per milligram of protein of which about half is present in the dentate gyrus and $1-2 \%$ releasable by strong depolarization (Chavkin et al., 1983 1985). Since each hippocampal slice contains approximately $0.74 \mathrm{mg}$ of protein (Neumaier et al., 1989), we can estimate that the releasable pool of dynorphin B in the guinea pig dentate gyrus is approximately $2-3 \mathrm{fmol}$. This rough calculation is solcly provided to suggest that amount of dynorphin applied by pressure pulse is likely to be greater than the amount released by granule cell stimulation in these experiments, and that the lack of effects seen after subgranular application were unlikely to be a result of insufficient drug application. The configuration of electrodes and pipette is shown in Figure $2 C$, inset; electrodes and pipettes were positioned approximately $200-300 \mu \mathrm{m}$ below the surface of the slice. After establishing a baseline response at the $S_{1 / 2}$, dynorphin B was pressure-ejected into the tissue (20-40 psi, 5-200 msec duration), and the slope and amplitude of the perforant path-evoked EPSPs were recorded every $10 \mathrm{sec}$ for $2 \mathrm{~min}$ and then every $30 \mathrm{sec}$ for $5 \mathrm{~min}$. For each slice tested, dynorphin B was applied to both the outer molecular layer and to the hilus just below the granule cell layer (the dynorphinIR subgranular axon plexus; see Fig. $3 E$ ) using the same drug pipette and application parameters, and the order was varicd. In some slices, the specificity of applied dynorphin action was tested by addition of NBNI to the perfusate before dynorphin application, and in other slices the dynorphin was replaced in drug pipettes with saline to control for possible pressure and vehicle artifacts.

\section{Fixation and preparation of sections for immunocytochemistry}

Four adult male Hartley guinea pigs (Charles River Labs, Wilmington, MA) were deeply anesthetized with sodium pentobarbital and perfused through the ascending aorta with $10 \mathrm{ml}$ of heparin-saline followed sequentially by $65 \mathrm{ml}$ of $3.75 \%$ acrolein and $2 \%$ paraformaldehyde in 0.1 M phosphate buffer, and then $200 \mathrm{ml}$ of $2 \%$ paraformaldehyde in $0.1 \mathrm{M}$ phosphate buffer. Brains were removed and stored in the latter fixative for $30 \mathrm{~min}$. Coronal or horizontal sections $(40 \mu \mathrm{m})$ were cut on a vibratome (vibrating microtome) through the entire extent of the hippocampal formation. Sections were collected in phosphate buffer and pretreated in $1 \%$ sodium borohydride in $0.1 \mathrm{~m}$ phosphate buffer prior to immunocytochemical labeling (Milner et al., 1989).

Antisera. Polyclonal rabbit antiscrum to dynorphin $\mathrm{A}_{1-8}$ was purchased from Peninsula Labs. The specificity of this antiserum was previously demonstrated using immunodot blots and immunoadsorption (Pickel et al., 1993). Mouse monoclonal antibody against leucine-enkephalin (LE) was also purchased (Sera Labs, Crawley Down, United Kingdom). This antibody has been previously characterized and tested for specificity by immunodot blotting and adsorption (Milner et al., 1989), and recognizes principally LE and methionine-enkephalin, although it cross-reacts slightly with three fragments of dynorphin $A$ (dynorphin $\mathrm{A}_{1-8}$, dynorphin $\mathrm{A}_{1-13}$, and dynorphin $\mathrm{A}_{1-17}$ ).

Polyclonal antisera against dynorphin $B_{1-13}$ and against $C$-peptide (the carboxyl terminal of dynorphin $B_{1-29}$ ) were a generous gift of Dr. Stanley Watson, Mental Health Research Institute, University of Michigan. The specificities of the dynorphin $B_{1-13}$ and C-peptide antisera were previously demonstrated by self-blocking and cross-blocking adsorption cxperiments (Neal and Neuman, 1989).

Immunocytochemistry. A modification of the avidin-biotin complex (ABC)-peroxidase technique was used (Hsu et al., 1981). Briefly, sections were processed through the following incubations with continuous 
A

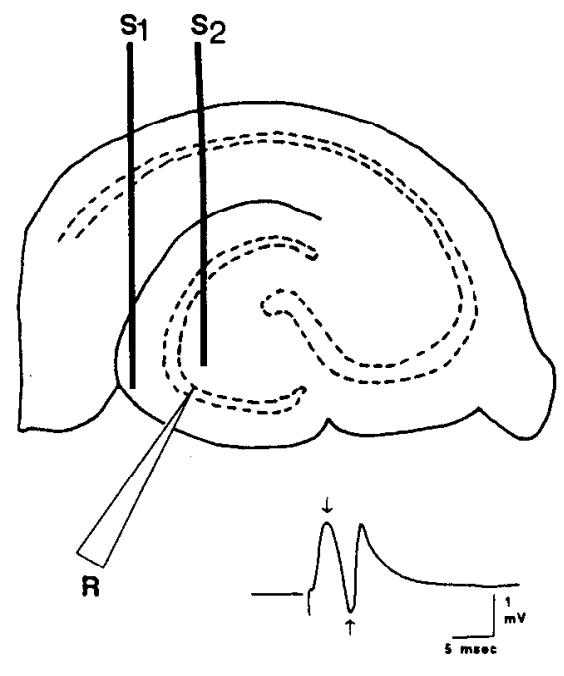

B
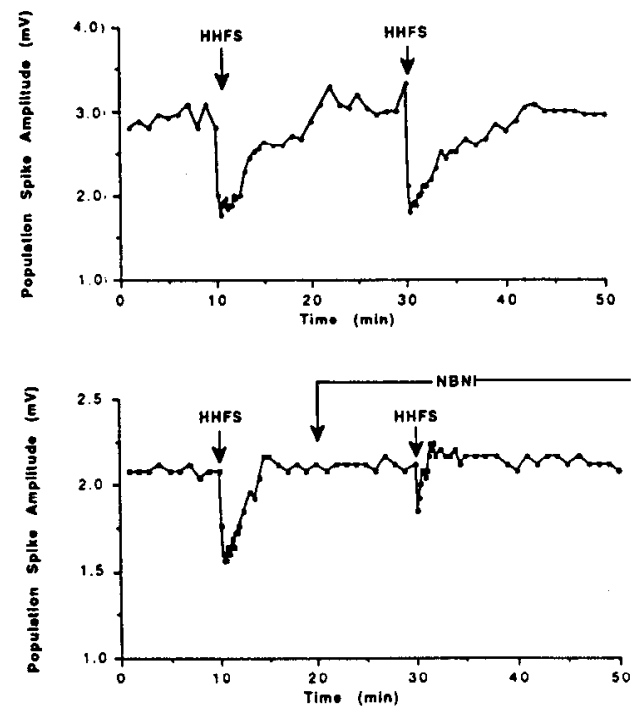

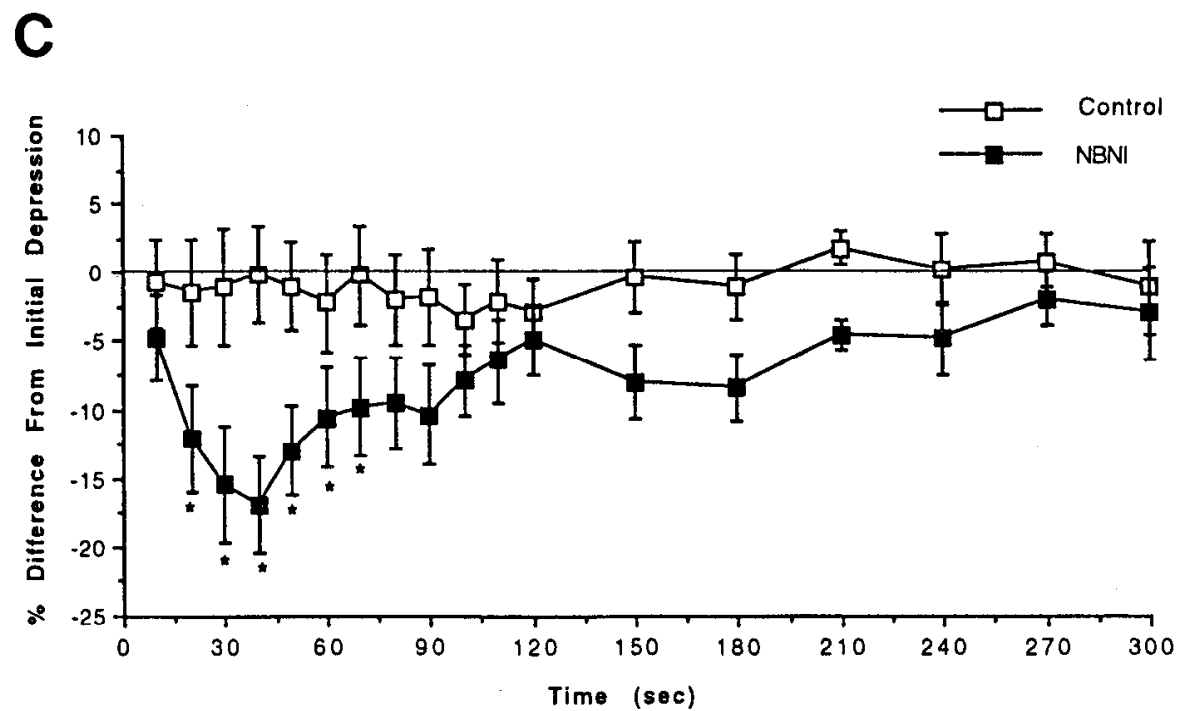

Figure 1. Depression of EPSPs following hilar HFS. A, Camera lucida drawing of representative slice used in the electrophysiological experiments. The placement of stimulating electrodes in the molecular layer $\left(S_{l}\right)$ and hilus $\left(S_{2}\right)$ and recording electrode $(R)$ in the granule cell layer in this experiment is indicated, along with a representative population spike recorded from the granule cell layer following stimulation of perforant path afferents (with electrode $S_{1}$ ) in the outer molecular layer. The population spike amplitude was measured as the difference in voltage between the first maximum and minimum potentials (arrows). B: Top, High-frequency stimulation in the hilus (HHFS) produced a transient depression of the population spike. A second HHFS consistently produced a similar depression. The HHFS consisted of six trains (each 1 sec long, at $50 \mathrm{~Hz}$ ) of pulses $(0.3 \mathrm{msec}, 300 \mu \mathrm{A})$ delivered every other second for $11 \mathrm{sec}$. Bottom, In a different slice than above, application of the $\kappa$ receptor antagonist NBNI before the second hilar HFS revealed an NBNI-sensitive component of the depression, indicating the involvement of endogenous dynorphin. $C$, The time course of NBNI-sensitive depression. Population responses following each HFS were converted to percentage of baseline determined as the mean of the five population responses immediately prior to the hilar HFS. Data shown are the differences between the first response to hilar HFS and the second response to hilar HFS. The second response to hilar HFS was measured either in normal Krebs-bicarbonate buffer (open squares) or in the presence of $100 \mathrm{~nm}$ NBNI (solid squares). The times listed on the horizontal axis are seconds following the end of the hilar stimulation period; thus, the $20 \mathrm{sec}$ measure is actually $31 \mathrm{sec}$ following the start of the hilar stimulation. The NBNI-sensitive component of the depression was significantly different $\left({ }^{*}, p<0.05\right)$ from depression in normal Krebs-bicarbonate buffer from 31 to 81 sec after beginning hilar stimulation.

agitation: (1) a 1:8000 dilution of dynorphin $A_{1-8}$ antisera, 1:16,000 dilution of dynorphin $B_{1-13}$ antisera, 1:25,000 dilution of C-peptide antisera, or a 1:200 dilution of LE antisera, for 12-16 hr, (2) biotinylated secondary antibody $(1: 400$ goat anti-rabbit IgG for sections incubated with antisera against dynorphins or C-peptide; 1:400 horse anti-mouse $\mathrm{IgG}$ for sections incubated with LE antisera) for $30 \mathrm{~min}$; (3) avidinbiotin-peroxidase complex (Vectastain Elite kit) at double the recommended dilution for $30 \mathrm{~min}$. The $A B C$ reaction produce was visualized following incubation of the tissue in 3,3'-diaminobenzidine (Aldrich) and hydrogen peroxide. All incubations were performed at room temperaturc. Scctions werc washed between incubations with $0.1 \mathrm{M}$ Tris saline. To aid antibody penetration, $0.25 \%$ Triton- $X$ was included in the primary antibody incubation of sections processed for light microscopy, and sections for electron microscopy were processed using the freeze-thaw technique (Descarries et al., 1992). Diluents consisted of 0.1 м Tris-saline (pH 7.6) with $0.1 \%$ bovine serum albumen. Sections processed for light microscopy were mounted on gelatin-coated slides, defatted and dehydrated through a graded series of alcohols and xylenes, 


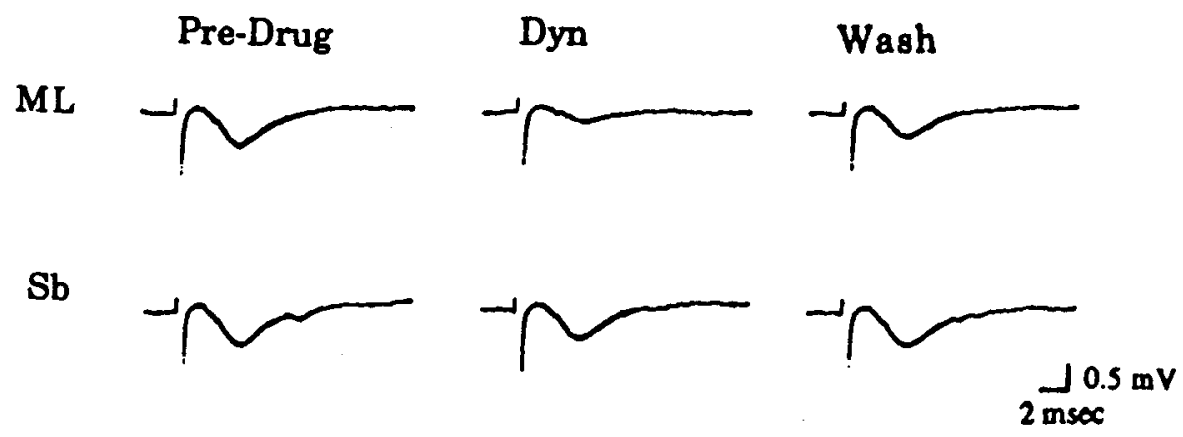

B

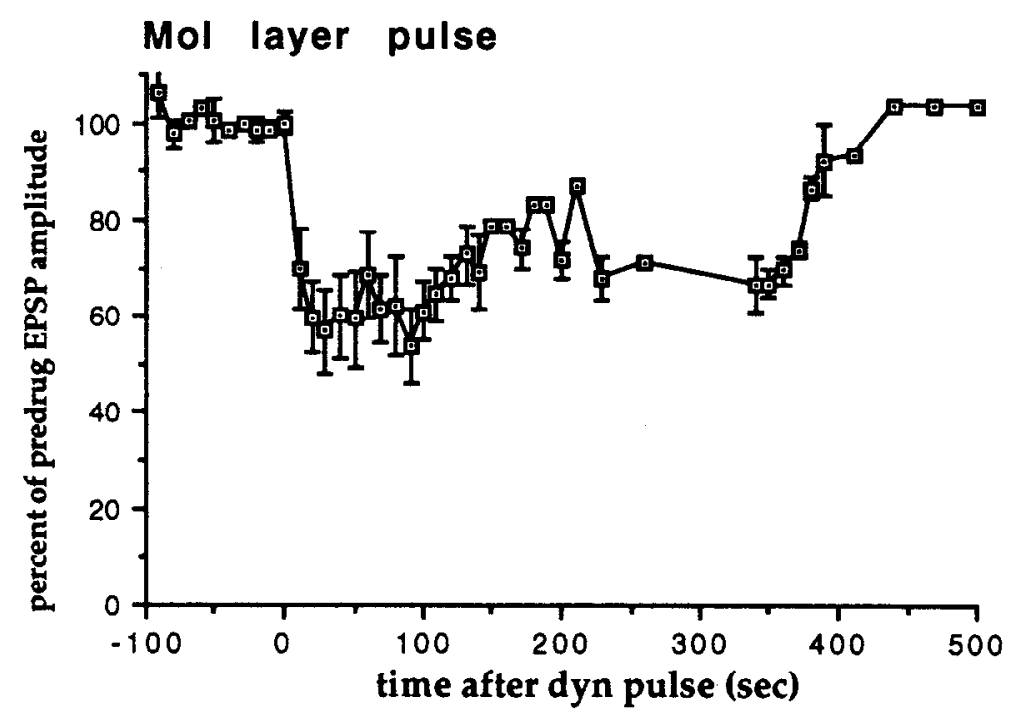

\section{Subgranular pulse}

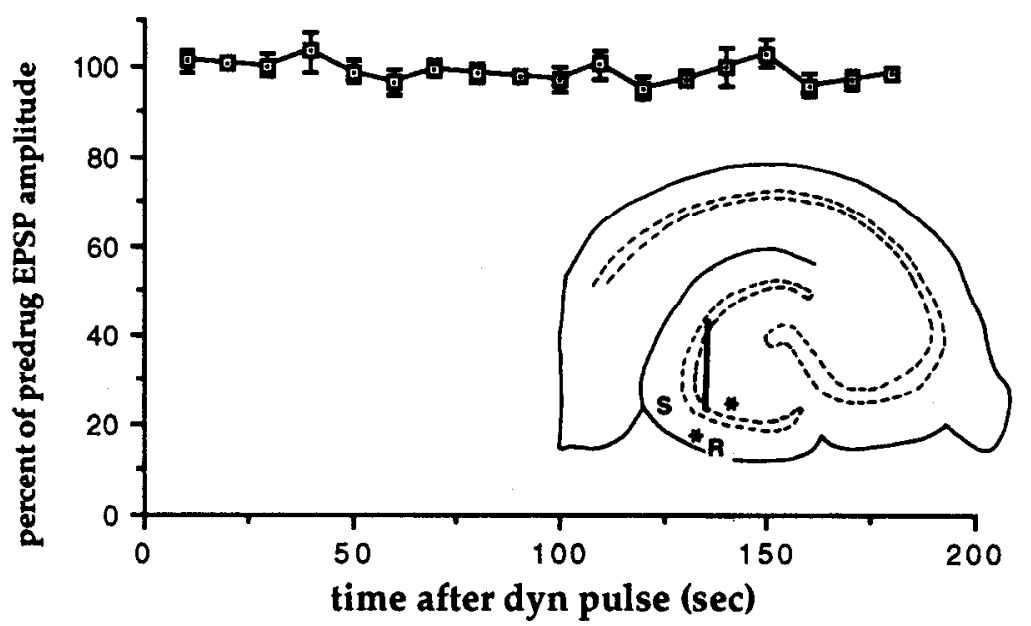

Figure 2. Effect of focal dynorphin B application in the molecular layer and the region of the hilus adjacent to the stratum granulosum (subgranular region). $A$, Traces showing the responses of field EPSPs recorded in the molecular layer to dynorphin B pressure application in the molecular layer $(M L$, upper three traces) and the subgranular region of the hilus ( $S b$, lower three traces). Application of dynorphin B in the molecular layer substantially depressed the EPSP, whereas subgranular dynorphin B application had a small and statistically insignificant effect. The same drug pipette and application parameters were used to deliver dynorphin $B$ in the two tissue locations. $B$, The average effect on EPSP amplitudes expressed as a percentage of predrug amplitude as a function of time following dynorphin B application at $t=0$ in the outer molecular layer (SE bars shown; $n=7$ ). Note that the onset of effect was rapid, within $10 \mathrm{sec}$ after a single pulse of dynorphin B $(100 \mu \mathrm{M})$. The same effect was seen in the field EPSP slope measure (data not shown). $C$, Effect of dynorphin B on EPSP amplitudes following application in the subgranular plexus. There was no significant effect of dynorphin application in the subgranular plexus ( $n=7, p>0.05$ ). Inset, Electrode and drug pipette configuration. $S$, stimulating electrode; $R$, recording electrode, solid bar, knife cut; *, placement of drug pipette either in the molecular layer near the recording electrode or in the subgranular region of the hilus.

and coverslipped in DPX (Aldrich). Tissue was examined and photographed on Nikon Microphot and Aus Jena Jenalumar microscopes using bright-field and differential interference contrast (DIC) optics.

For electron microscopy of immunolabeled tissue, labeled sections of hippocampal formation were fixed in $2 \%$ osmium tetroxide in phosphate buffer for $1 \mathrm{hr}$, embedded in Epon as previously described (Milner and Veznedaroglu, 1992). Regions through the molecular layer of den- tate gyrus crest and ventral blade were selected in sections with morphological correspondence to slices used for electrophysiology (see Fig. $6 A)$. Ultrathin $(50 \mathrm{~nm})$ sections of this region were collected on copper grids and counterstained with uranyl acetate and lead citrate (Milner and Veznedaroglu, 1992). Sections were examined and photographed on a Philips 210 or a Philips 300 electron microscope.

Fixation and preparation of additional unlabeled sections for electron 

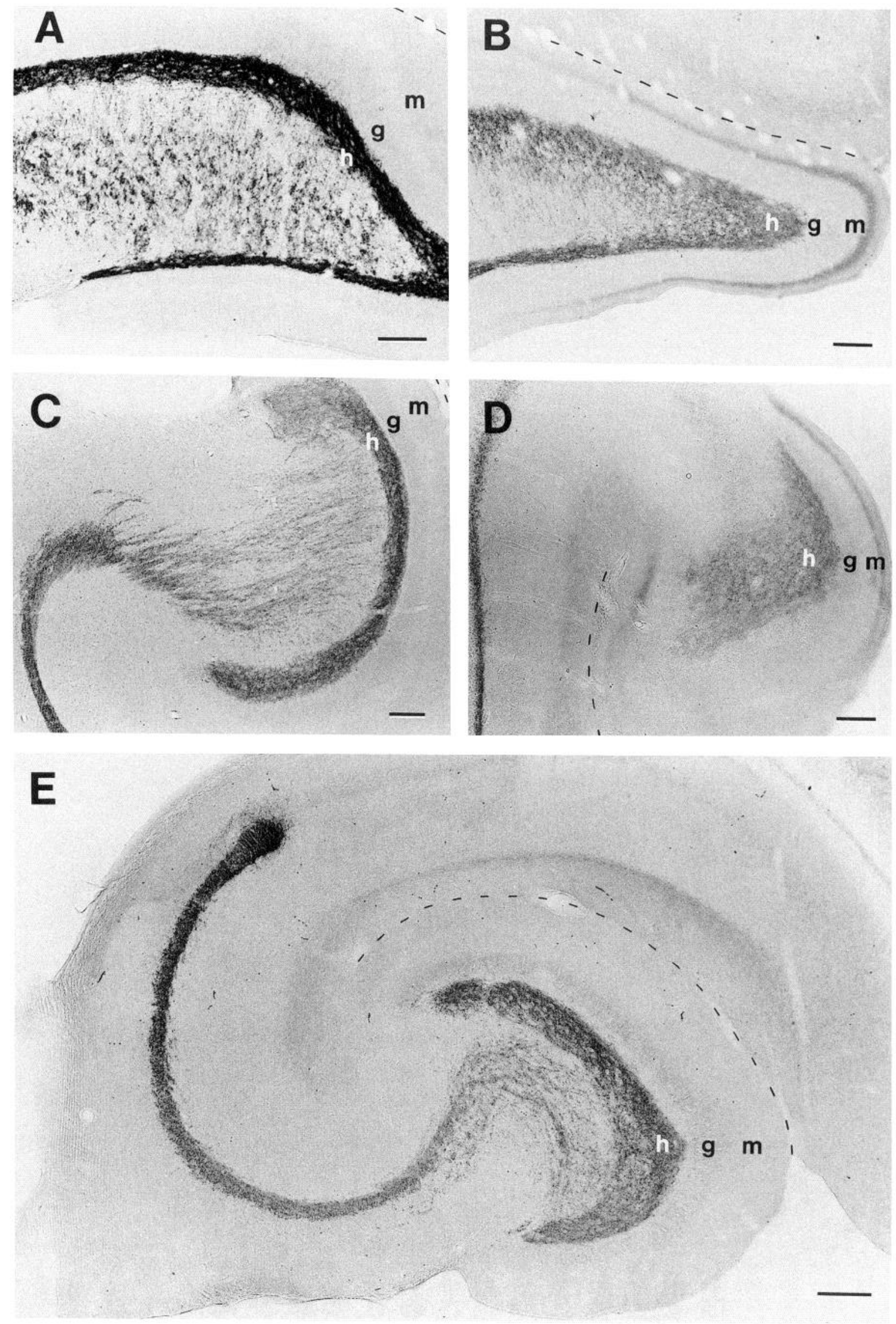
microscopy. Two male Hartley guinea pigs (Simonsen Labs, Gilroy, CA) were deeply anesthetized with sodium pentobarbital and perfused through the ascending aorta with $10 \mathrm{ml}$ of heparin-saline followed by $200 \mathrm{ml}$ of $2 \%$ paraformaldehyde with $0.2 \%$ glutaraldehyde in $0.1 \mathrm{M}$ sodium cacodylate buffer $(0.1 \mathrm{M}, \mathrm{pH} 7.4)$. Brains were removed and postfixed in the same fixative overnight. Hippocampi were removed, and a razor blade was used to cut transverse sections approximately $1 \mathrm{~mm}$ thick and then to isolate the dentate gyrus. Tissue blocks were rinsed in 0.1 $\mathrm{M}$ cacodylate buffer, osmicated ( $1 \%$ osmium in $0.15 \mathrm{M}$ cacodylate buffer), rinsed again, and embedded in Medcast. Ultrathin sections were cut and stained with uranyl acetate and lead citrate as above. Sections were examined and photographed on a Philips 410 electron microscope.

Analysis of dynorphin distribution in the molecular layer. Initial analysis of 10 horizontal sections from two animals revealed that dynorphinlike immunorcactivity (dynorphin-LI) was primarily associated with dense-core vesicle (dcv) profiles. Dcv profiles were identified based on their characteristic appearance as spherical or ovoid organelles, 80-120 $\mathrm{nm}$ in diameter, with distinguishable outer membranes enclosing lumens and uniformly dark cores. Some profiles that were probably dcvs but that did not clearly fit the above criteria due to obscuring reaction product were excluded from the counts. The location of labeled dcvs was categorized as axonal, dendritic, or unknown. A labeled dcv profile was classified as axonal if it was in a process with no rough ER and at least two small clear synaptic vesicles, dendritic if in an obvious dendritic spine or shaft defined by the presence of rough ER and absence of small clear synaptic vesicles. Labeled dcv-containing processes that did not meet all of the criteria for axons or dendrites were classified as unknown.

To calculate the percentages of dynorphin-ir dcv profiles in each third of the molecular layer, sections that contained well-preserved molecular layers were carefully sketched on graph paper, using the $100 \mu \mathrm{m}$ squares of the copper EM grid and the lines on the graph paper to keep the dimensions of the sketch accurate. The locations of granule cells and blood vessels were included on the sketches as reference points. A 100$\mu \mathrm{m}$-wide track (the width of one square on the copper sample-holding grid) running from the superficial to deep extremes of the molecular layer was chosen slightly into the exposed blade of the dentate gyrus, generally parallel to the orientation of the granule cell dendrites. This region was selected to correlate with the site of endogenous dynorphin effects on synaptic transmission in the electrophysiological experiments of this study. The distance along the track from superior edge of granule cell layer to the superior edge of molecular layer was measured on the sketch and divided by 3 . The grid squares comprising the track were then examined on the clectron microscope and dynorphin-labeled devs were counted in each third of the molecular layer. In addition to comparing the relative dynorphin content of the inner, middle, and outer molecular layer, the relative levels of dynorphin in axons versus dendrites were determined for each sample as a percentage of total dynorphin along the track in that sample. Comparisons were made by calculating the distribution of dcvs with dynorphin-LI in each slice as a percentage of total dynorphin-labeled dcvs in that slice, and statistical significance of apparent differences in distribution was determined by two-way analysis of variance.

\section{Results}

Time course of physiological effects of endogenous dynorphin High-frequency stimulation of the hilus (see Fig. $1 A$ for electrode placement) led to depression of the granule cell population response (Fig. 1B) evident at the first time point measured (21 sec after beginning the $11 \mathrm{sec}$ stimulation train). The depression was reproducible as a second response with similar onset, magnitude, and duration could consistently be produced by repeating the hilar high-frequency stimulation train (Fig. $1 B, C$ ). In slices perfused with the $\kappa$ receptor antagonist NBNI, the second hilar high-frequency stimulation was much less effective in causing a depression (Fig. 1B). In these slices, both NBNI-sensitive and NBNI-insensitive components of the depression were evident (Fig. 1B). The onset of a NBNI-sensitive depression of the population spike was fast, showing statistical significance within $31 \mathrm{sec}$ after beginning the $11 \mathrm{sec}$ hilar high-frequency stimulation (Fig. 1C). While the onset of dynorphin action was slower than the millisecond required for GABA or glutamate neurotransmission in this region, this time frame suggests that the peptide diffuses only a short distance as discussed below (Nicholson, 1988/1989).

\section{Electrophysiological responses to applied dynorphin}

The dendritic field EPSP recorded in the molecular layer was substantially depressed by dynorphin B application in the molecular layer but was not significantly diminished by dynorphin $B$ application in the subgranular region of the hilus (Fig. 2). This difference is evident in the oscilloscope traces of the EPSP response (Fig. $2 A$ ) and in graphic representations of the EPSP amplitude and slope (Fig. $2 B, C$ ). The maximal depression of the EPSP (which occurred 20 or $30 \mathrm{sec}$ after drug application) was measured in seven slices. Following dynorphin B application in the molecular layer, the average peak depressions of the EPSP amplitude and slope were $48 \pm 7 \%$ and $45 \pm 6 \%(n=$ 7). Following subgranular application of dynorphin B, the average depressions of the EPSP amplitude and slope were less than $5 \%$ and not significantly different from baseline. The effects of dynorphin B application in the molecular layer were blocked by pretreatment with $100 \mathrm{nM}$ NBNI $(n=3)$ and not mimicked by equivalent application of vehicle alone (data not shown). The differences in dynorphin $\mathrm{B}$ action between drug application sites were significant $(p<0.05)$ by unpaired $t$ test and Wilcoxon signed rank tests. The lack of effect of subgranular administration was not a result of insufficient peptide application: the same pipette was used in both sites for each slice, drug flow was checked before and after the determination, and the amount of peptide delivered by the $0.1-1.0 \mathrm{nl}$ droplet was calculated to be greater than the releasable pool of endogenous dynorphin B present in the dentate gyrus. The greater sensitivity of the excitatory synaptic response to dynorphin B application further suggests that endogenous dynorphin actions in the molecular layer are likely to be mediated by a local source of peptide rather than a distant source in the hilus.

\section{Light microscopic localization of dynorphin-like immunoreactivity}

As previously reported (McLean et al., 1987), the guinea pig dorsal or anterior hippocampus contained dense dynorphinlabeled processes in the hilus and stratum lucidum of region $\mathrm{CA} 3$ (Fig. 3A,C). Staining was absent in a narrow zone of the hilus immediately adjacent to the granule cell layer and was observed in only a few scattered fibers in the molecular layer.

\footnotetext{
Figure 3. Light microscopy of dynorphin-like immunoreactivity in the dentate gyrus in coronal and horizontal sections. $A$, Dynorphin $\mathrm{A}_{1-8}$ labeling in a coronal section from dorsal hippocampus. $B$, Dynorphin $\mathrm{B}_{1-13}$ labeling in a coronal section from ventral hippocampus. $C$, Dynorphin $\mathrm{A}_{1-8}$ labeling in a horizontal section from dorsal hippocampus. $D$, Dynorphin $\mathrm{A}_{1-8}$ labeling in a horizontal section from ventral hippocampus. In all sections, intensely labeled fibers were present in the hilus and stratum lucidum, with occasional lightly labeled fibers in the granule cell and molecular layers. In sections from ventral (temporal) hippocampus, an additional band of labeling was also evident in the molecular layer $(B, D$ ). $E$, Dynorphin $B_{1-13}$ labeling in a horizontal section with transverse morphology comparable to slices used in electrophysiological experiments. The band of dynorphin-LI in the molecular layer observed in sections from the ventral pole was not present at this level. Scale bars, $200 \mu \mathrm{m}$.
} 

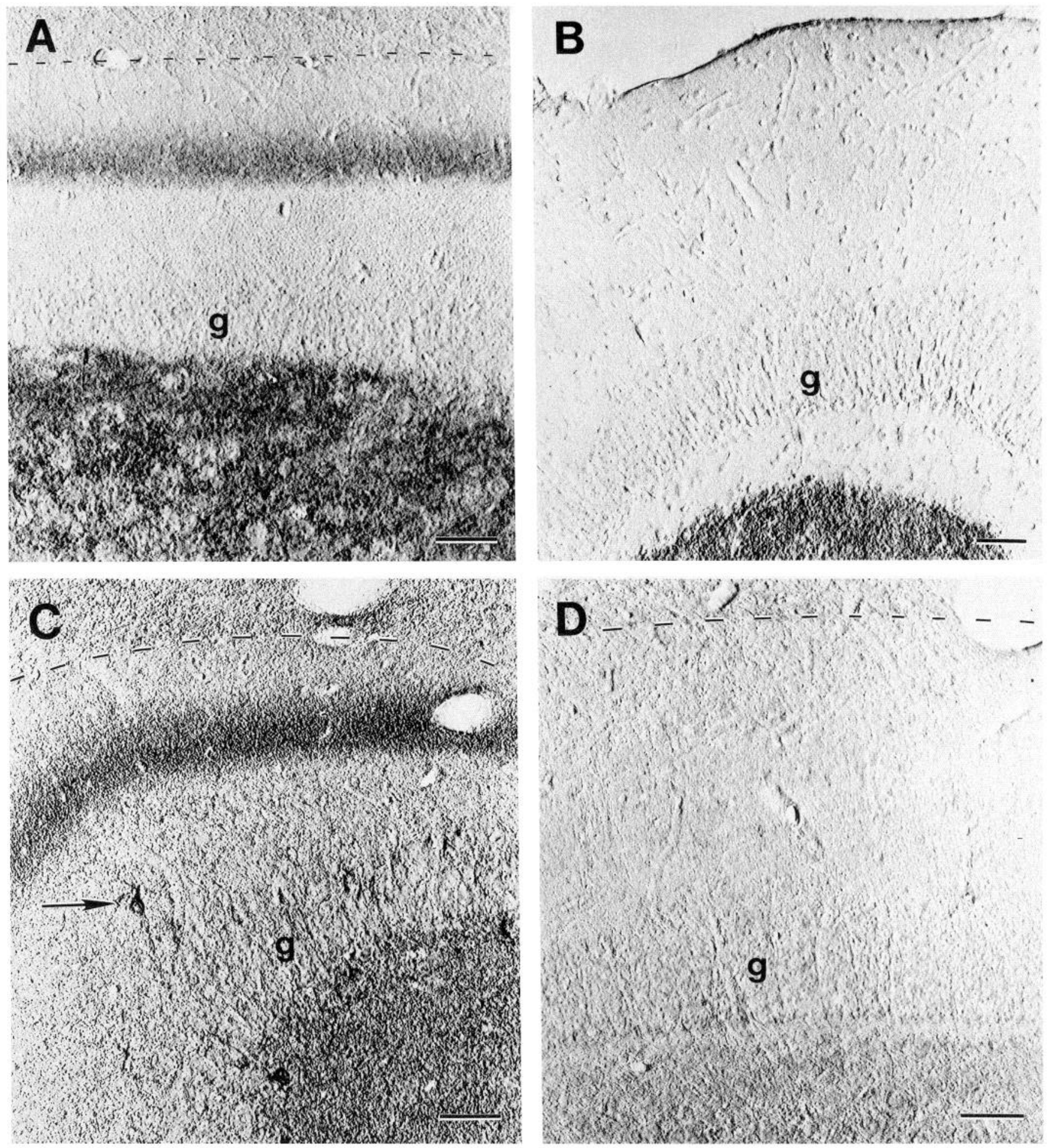

Figure 4. High-magnification DIC light microscope photomicrographs of sections of dentate gyrus labeled with antisera to various opioid peptides. $A$, Dynorphin $\mathrm{A}_{1-8}$ labeling in the ventral pole of the hippocampus. The band in the molecular layer contains diffuse reaction product and thin varicose fibers. $B$, Dynorphin $A_{1-8}$ labeling in a horizontal slice with transverse morphology as in Figure $3 E$. Note the absence of a band in the molecular layer. $C$, Leucine-enkephalin-like immunoreactivity (LE-LI) in a ventral slice comparable to $A$. In addition to the hilar and molecular layer labeling, cells with LE-LI (arrow) were present in granule cell layer, molecular layer, and hilus. $D$, Ventral section labeled with antisera to the C-terminus of leumorphin. Labeling was virtually absent in the dentate gyrus. $g$, granule cell layer; dashed line, hippocampal fissure. Scale bars, $50 \mu \mathrm{m}$. 

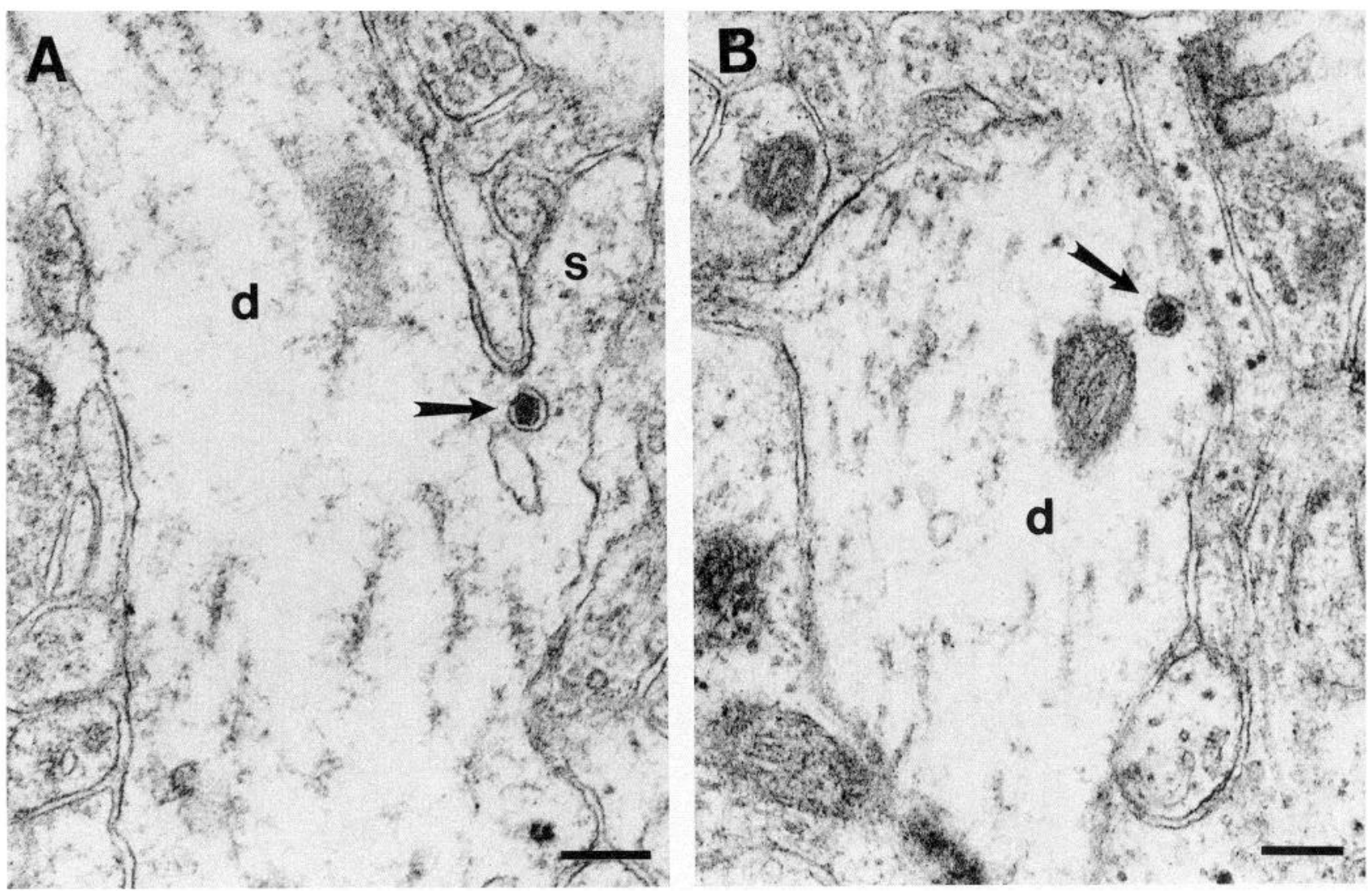

Figure 5. Electron micrographs showing the normal morphology of dense-core vesicle profiles in dendrites in the molecular layer in unlabeled tissue. A, A dense-core vesicle profile (arrow) at the base of a dendritic spine. $B$, A dense-core vesicle (arrow) in the shaft of a dendrite. $d$, dendrite; $s$, spine. Scale bars, $200 \mathrm{~nm}$.

This pattern held true through most of the anterior-posterior and dorsal-ventral extent of the hippocampus. However, at the extreme temporal (i.e., ventral) pole, a band of dynorphin-LI was present in the molecular layer at the transition between the middle and outer thirds of the molecular layer (Fig. $3 B, D$ ). At higher magnifications, the band exhibited darkly stained varicose fibers (Fig. 4A). Although these bands represent an obvious source of dynorphin in the guinea pig molecular layer, they were absent in sections from more dorsal levels of the hippocampus (Figs. $3 A, C, E ; 4 B$ ), notably in sections corresponding to slices used for the electrophysiological experiments (compare Figs. 1, $3 E)$.

Comparison of the two antisera to dynorphin revealed no differences in the pattern of dynorphin $\mathrm{A}_{1-8}$ and dynorphin $\mathrm{B}_{1-13}$ labeling. Sections labeled with LE antisera showed overlapping staining with dynorphin, and additionally labeled cell bodies were seen in molecular layer, granule cell layer, and hilus (Fig. $4 C$ ). Unexpectedly, guinea pig hippocampus showed no significant labeling with antisera to the extended dynorphin B precursor, C-peptide (Fig. 4D).

Electron microscopy. Initial analysis of the molecular layer of the dentate gyrus from unlabeled tissue revealed large densecore vesicle (dcv) profiles in both dendrites (Fig. 5) and axons (not shown). Axonal and dendritic dcvs were round or ovoid organelles $80-120 \mathrm{~nm}$ in diameter, composed of an outer membrane, a lumen, and a solid dark core. In axons, dcv profiles were observed in and near clusters of small clear vesicles, and as previously described, they were usually not immediately ad- jacent to presynaptic membrane specializations (Zhu et al., 1986). In dendrites, dcv profiles were most commonly in or near spines, and were not associated with any visible membrane specializations (Fig. 5). Many of the axon terminals containing dcv profiles formed asymmetric synapses, and dcv-containing dendrites were recipient to terminals forming asymmetric synapses (data not shown).

Analysis of the same region in tissue labeled for dynorphinLI revealed that dynorphin-LI was largely concentrated over some of the same structures previously identified in unlabeled tissue as dcvs, that is, round or ovoid organelles with an outer membrane, a dark core, and diameters ranging from 80 to 120 nm (Figs. 6, 7). Reaction product was also occasionally observed within the cytoplasm adjacent to labeled vesicles (Fig. 6D), and (in axons only) rimming microtubules and mitochondria in a fashion previously described (Milner and Veznedaroglu, 1992). Dcv profiles with dynorphin-LI were observed in the molecular layer in both axons (Fig. $6 C$ ) and spiny dendrites (Figs. $6 A, B, D$; $7 B-D$ ). Axonal dynorphin-LI was seen in unmyelinated fibers, along with clusters of unlabeled small clear vesicles (Fig. 6C). Within dendrites, dynorphin-LI dcv profiles were often found in or very near spines (Figs. $6 B, D ; 7 B, D$ ) and less commonly in dendritic shafts (Figs. $6 A, 7 C$ ). In both axons and dendrites, dynorphin-LI dcvs were not localized near any visible pre- or postsynaptic membrane specializations.

The distribution of dynorphin-LI dcvs was more closely examined in transverse horizontal sections with the same morphology as hippocampal slices used in the physiological studies. 

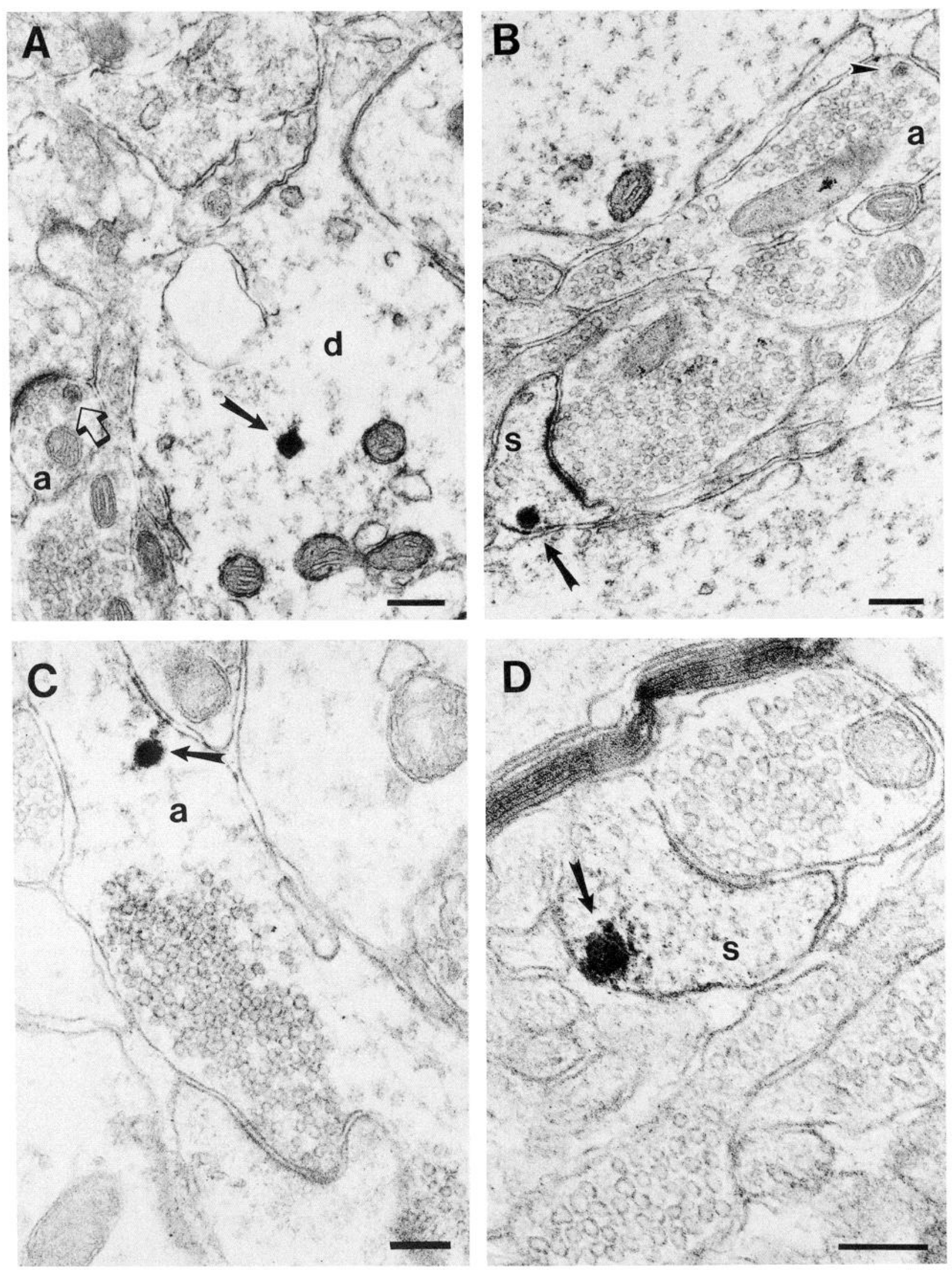

Figure 6. Dynorphin-like immunoreactivity in the molecular layer. In $A-D$, immunoreactivity was primarily localized over dense-core vesicle profiles. $A$, Labeled dcv profile in a dendritic shaft (solid arrow). An unlabeled dcv is also present in a nearby axon (open arrow). $B$, Dendritic dcv (solid arrow) in a spine head that receives an asymmetric synapse from an unlabeled axon. An unlabeled dcv profile is also present (arrowhead) in a nearby axon. $C$, Labeled dcv profile (solid arrow) in an axon. $D$, Reaction product concentrated over a dcv profile (solid arrow) and adjacent cytoplasm in a spine head contacted by an unlabeled axon forming an asymmetric synapse. $a$, axon; $d$, dendrite; $s$, spine. Scale bars, 200 nm. 

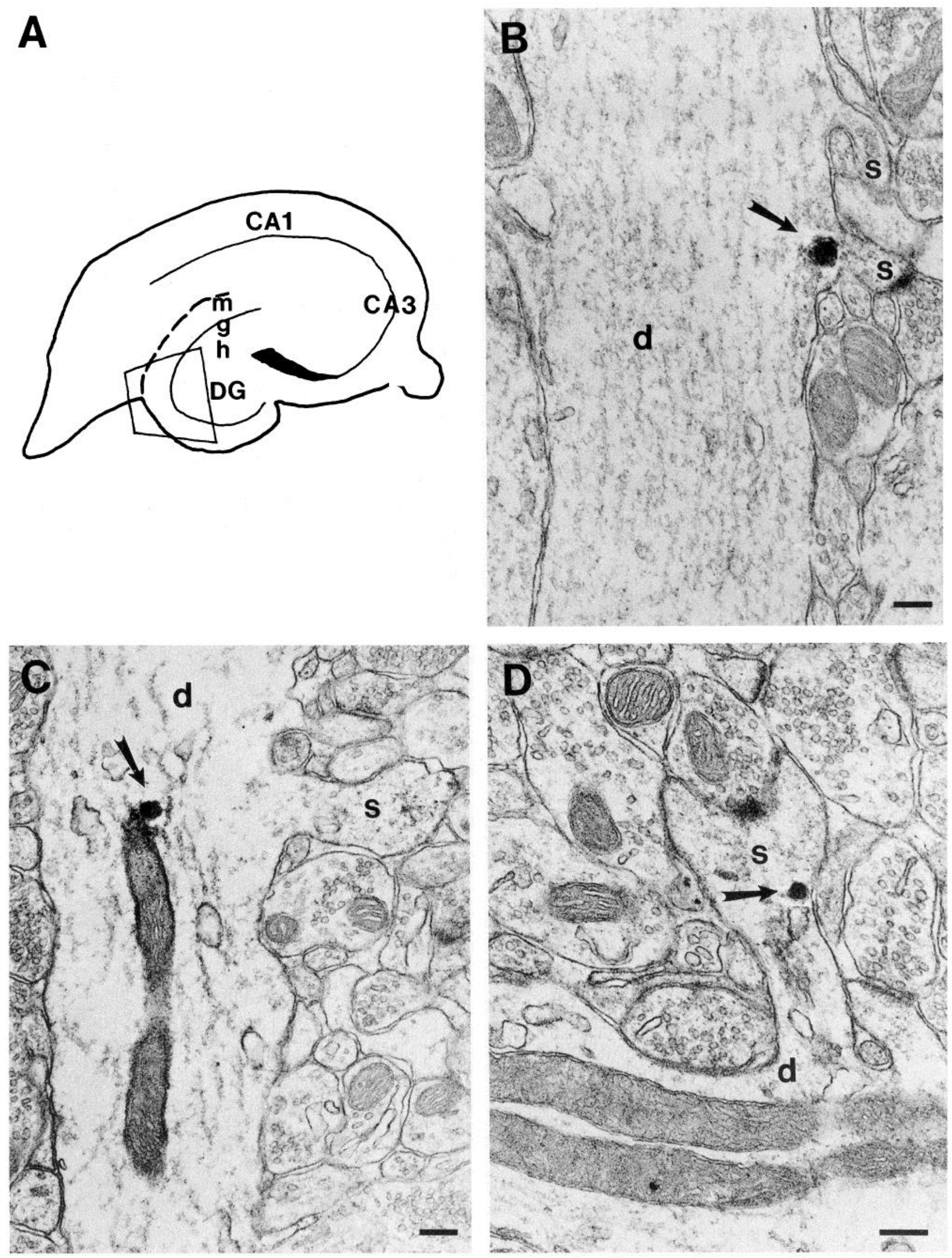

Figure 7. Dynorphin-LI dendrites are found throughout the molecular layer in transverse horizontal sections. $A$, Camera lucida drawing o representative transverse horizontal section corresponding to slices used in electrophysiological experiments. Outlined area indicates the region the dentate gyrus examined ultrastructurally. $B$, An example of a dynorphin-immunoreactive dcv profile (arrow) in a dendrite of the inner molecu layer. Note the presence of simple spines. $C$ and $D$, Dendrites containing dynorphin-ir dcvs in the middle and outer molecular layers, respective Spines on these dendrites are more complex than shown in $B . d$, dendrite; $s$, spine. Scale bars, $200 \mathrm{~nm}$. 


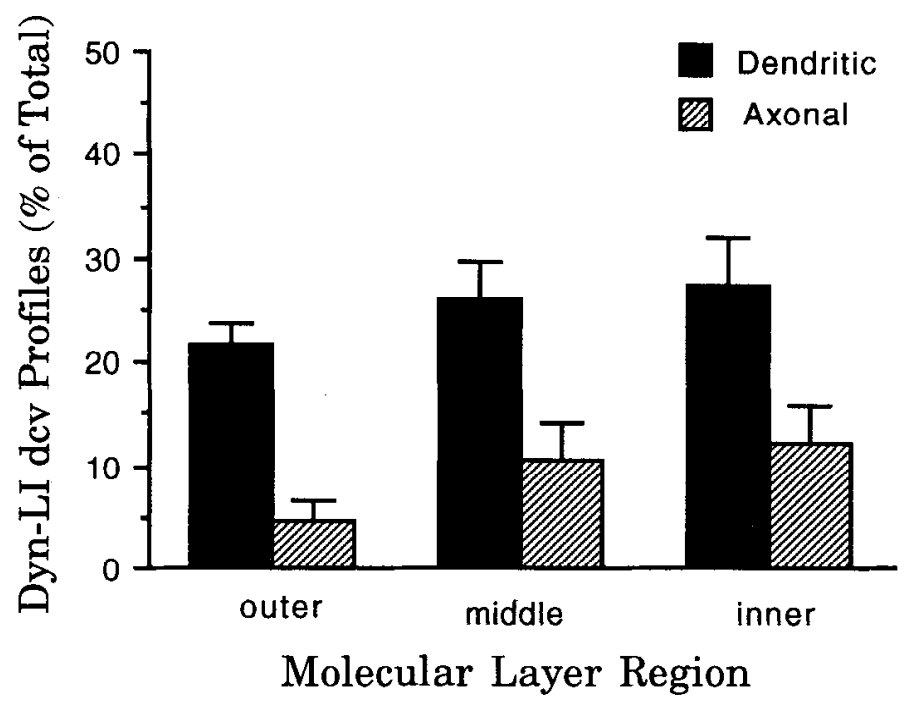

Figure 8. Dynorphin-LI dcvs are more common in dendrites than in axons in the molecular layer. Dynorphin-labeled dcv profiles were counted on the electron microscope along a $100 \mu \mathrm{m}$ track from outer to inner molecular layer in 10 transverse horizontal sections from two animals. No differences were observed in sections labeled with dynorphin $A_{1.8}$ and dynorphin $B_{1-13}$, so the counts were pooled. The percentage of dynorphin-LI in dendrites (solid bars) and axons (hatched bars) was determined relative to the total number of dynorphin-LI dcvs in identified processes in that section (range $=6-34$, average $=15$ ). Two-way ANOVA revealed that significantly more dynorphin-LI was located in dendrites than in axons in all regions of the molecular layer. There were no significant differences in content between dendrites in different molecular layer regions or between axons in different regions.

To maximize the correlation between the electron microscopic and physiological studies, this examination was restricted to the dentate gyrus crest region and an adjacent portion of the exposed blade (compare Figs. $1 A, 7 A$ ). As in other samples of the molecular layer, in transverse horizontal sections labeled dcv profiles were seen in axons (not shown) and spiny dendrites throughout the molecular layer (Fig. $7 B-D$ ). Labeled dendrites in the inner one-third of the molecular layer tended to be large diameter with relatively simple spines (Fig. $7 B$ ) while in the outer two-thirds the labeled dendritic shafts were usually smaller and the spines more complex (Fig. 7C,D).

Inspection of the molecular layers of transverse horizontal sections revealed many more dynorphin-LI dcvs in dendrites than in axons. This observation was quantified by tabulating dynorphin-LI dcvs along a $100-\mu \mathrm{m}$-wide track from outer to inner extreme of the molecular layer near the crest of the dentate gyrus (see Materials and Methods for details). The average total number of dynorphin-I.I dcvs in a single track was 23, with labeled dcvs in identified processes averaging 15 per track (range, 6-34). In each section, one-third of the labeled dcvs were located in processes that either (1) did not meet all of the criteria for classification into the axonal or dendritic groups, (2) were damaged during fixation or freezing such that the contents of neighboring axons and dendrites may have mixed, or (3) were damaged or sectioned so as to make the processes unrecognizable. Processes that met some but not all of the criteria for categorization included both probable axons and dendrites, but these were not included in the identifiable category. Among identifiable processes, dynorphin-LI was significantly more abundant in dendrites than axons in each region (inner, middle, and outer molecular layer) by two-way ANOVA (Fig. 8). The percentages of dendritic dynorphin-LI were not significantly different bctween the three regions of the molecular layer, although there was a gradient decreasing toward the granule cell layer (Fig. 8). Likewise, the percentages of axonal dcvs were not significantly different between the three regions, although there was a trend toward increasing prevalence closer to the granule cell layer (Fig. 8). In comparison to the transverse sections, sections from the extreme ventral pole of the hippocampus appeared to contain similar amounts of dendritic dynorphin-LI and more axonal dynorphin-LI in the molecular layer, corresponding to the band observed in the molecular layer by light microscopy. Because the focus of this study is on those hippocampal regions relevant to the physiological studies, these latter observations were not further quantified.

\section{Discussion}

This study presents physiological and anatomical evidence that the molecular layer contains a source of dynorphin that may act to modulate perforant path induced excitation of granule cells. Our hypothesis is supported by the following new findings, which are listed and then discussed sequentially below. (1) The rate of onset of dynorphin action following stimulation was rapid (within seconds), and calculations based on an estimated diffusion coefficient for dynorphin suggest that the source of peptide was within $70 \mu \mathrm{m}$ of the site of action. (2) Application of dynorphin B was effective when applied in the molecular layer near the site of peptide action, but ineffective when applied in the hilus near the dynorphin-rich axonal plexus. (3) Ultrastructural analysis of the dentate molecular layer revealed the presence of a low level of dynorphin-immunoreactive densecore vesicles, with $74 \%$ found in spiny dendrites of granule cells, and $26 \%$ in unmyelinated axons. These results suggest that under conditions of intense afferent activation, the granule cell can release dynorphin-opioids from either dendrites or recurrent axons to activate $\kappa_{1}$ receptors on presynaptic terminals of the perforant path and thereby reduce the excitatory transmitter release for tens of seconds to minutes. The significance of these findings is that they address the larger question of the properties of endogenous neuropeptide synapses in the mammalian brain by providing new detail to our understanding of the anatomical organization and synaptic physiology of opioid action in the dentate gyrus.

Kinetics of endogenous opioid action. Hilar stimulation released endogenous opioid peptides that depressed the perforant path excitation of granule cell dendrites in an NBNI-sensitive fashion. Previous work indicated that endogenous dynorphins act on presynaptic $\kappa_{1}$ receptors to reduce glutamate release from perforant path terminals in the molecular layer (Wagner et al., $1991,1992,1993)$. In the present study, the onset of endogenous dynorphin actions was examined more closely, and effects were found to be evident within $21 \mathrm{sec}$ and statistically significant by $31 \mathrm{sec}$ following the initiation of peptide-releasing stimulation. Our results do not exclude the possibility that dynorphin effects occurred even earlier than $20 \mathrm{sec}$ but were not prevented by NBNI due to transiently high local concentrations of dynorphin at molecular layer $\kappa$ receptors. The kinetics of the response measured include the time required for release, diffusion to site of action, activation of response, and clearance from the site of action. Nevertheless, we can calculate how far the peptide can diffuse in $20 \mathrm{sec}$ based on an estimate of the diffusion constant. The diffusion constant of dynorphin in water is likely to be similar to other peptides of the same size, $4 \times 10^{-6} \mathrm{~cm} / \mathrm{sec}$ 
(Schenk et al., 1991). Adjusting this for the increased tortuosity of the extracellular space and charge interactions between diffusing cations and polyanionic glycosaminoglycans in the extracellular matrix (Rice et al., 1985) gives an effective diffusion coefficient of about $4 \times 10^{-7} \mathrm{~cm} / \mathrm{sec}$; however, while this may be a reasonable estimate, we have not empirically determined the effective diffusion coefficient of dynorphin $\mathrm{B}$ in the brain slice. Using Fick's law of diffusion $\left(r^{2}=6 D^{*} t\right.$, where $r$ is the radius of diffusion in the three-dimensional space, $D^{*}$ is the effective diffusion coefficient, and $t$ is time) (Hille, 1992), the peptide would be expected to move about $70 \mu \mathrm{m}$ in $20 \mathrm{sec}$ on average. Because the highly charged dynorphins are known to be exceptionally "sticky" (Ho et al., 1980), the diffusion coefficient is likely to be a conservative overestimate and the diffusion distance less. As the $20 \mathrm{sec}$ onset time also includes the time required for peptide release, peptide diffusion, and peptide action, the diffusion distance estimate is realistically an upper limit. Thus, the rapidity of dynorphin's actions in this physiologic system suggests that dynorphin was released from local sites closer to the molecular layer $\kappa$ receptors than the hilar stores of dynorphin several hundred micrometers away.

This hypothesis was supported by the lack of significant effect produced by dynorphin B application in the hilus. The effectiveness of dynorphin B application in the molecular layer was not unexpected, as this is the location of both the perforant path terminals and $\kappa_{1}$ receptors. Additionally, the amount of dynorphin $B$ applied by the pipette pulse is large in comparison to the dynorphin peptide content of the dentate gyrus (Chavkin et al., 1983, 1985). The lack of effect following application in the subgranular plexus of the hilus was also not unexpected since diffusion from a source more than $300 \mu \mathrm{m}$ away (as measured in the slice) would take more than $6 \mathrm{~min}$ as calculated using the effective diffusion coefficient for dynorphin $B$ defined above. The results presented for dynorphin $B$ application support two conclusions: first, that the molecular layer is the likely site of dynorphin action, and second, that the source of endogenous dynorphin is likely to be near the sites of action, within the molecular layer.

Dynorphin-containing dense-core vesicles in the molecular layer of the dentate gyrus. Although virtually no dynorphin immunoreactivity was observed in the molecular layer of transverse horizontal sections at the light microscopic level, a principal finding of this study was the ultrastructural observation that low levels of dynorphin-containing dcvs were evident in the molecular layer. Both identified dendrites and axons contained labeled dcvs, but the majority (74\%) were in dendrites near the putative site of dynorphin action on perforant path terminals. Considerable evidence suggests that the molecular layer dynorphincontaining dendrites observed in this study originate from granule cells. Previous studies have localized almost all dentate dynorphin-LI and prodynorphin mRNA to the granule cells (McGinty et al., 1983; Morris et al., 1988). In our study, the dynorphin-containing dendrites were observed to originate from granule cell somata in a few of the images of the inner molecular layer. In the outer two-thirds of the molecular layer, the morphology of dynorphin-containing processes was characteristic of granule cell dendrites: the dendritic processes possessed a large numbers of spines and received both perforated and nonperforated synapses onto spines and shafts. The spines were generally more complex and the dendritic shafts smaller in diameter in the outer two-thirds than in the inner third of the molecular layer. These characteristics correlate precisely with previously described granule cell dendrites (Blackstad, 1963; Laatsch and Cowan, 1966). In contrast, the dendrites of most inhibitory interneurons of the dentate gyrus are distinctly aspinous or sparsely spiny (Amaral, 1978). Although populations of spiny cells in the hilus have been described (Ramon y Cajal, 1911; Lorente de No, 1934; Blackstad, 1963; Amaral, 1978; Ribak et al., 1985), in guinea pig these cells tend not to send dendrites into the molecular layer (Scharfman and Schwartzkroin, 1988; but see Scharfman, 1991), and there is no evidence that these nongranule cells contain dynorphin.

The origins of dynorphin-labeled axons in the molecular layer are much less clear. In guinea pig, a portion of the perforant path has been reported previously to contain proenkephalinderived peptides (Tielen et al., 1982). Yet, it is unlikely that the dynorphin-LI observed in our study was due to cross-reaction of dynorphin antisera with enkephalin, since neither antiserum significantly recognized enkephalin in specificity tests (Neal and Newman, 1989; Pickel et al., 1993). The presence of dynorphin in fibers of the perforant path has been previously suggested (Kanamatsu et al., 1986; McGinty, 1993), and our results show dynorphin-LI along the temporammonic tract that also originates in entorhinal cortex (Fig. $3 D, E$ ). However, previous studies using a radioligand displacement measure of dynorphin release indicated that the perforant path was unlikely to be the source of the released dynorphin (Wagner et al., 1991). Specifically, dynorphin release following activation of perforant path fibers could be blocked by the glutamate receptor antagonist CNQX, indicating that a postsynaptic source (i.e., granule cells) predominated.

Although some of the dynorphin-containing axons may belong to the perforant path, an additional source must be postulated since the perforant path projects only to the outer twothirds of the molecular layer (Hjorth-Simonsen, 1972; Steward, 1976), and axonal dynorphin-containing devs were seen in throughout the molecular layer. A possible source of some dynorphin-containing axons is the recurrent collaterals from granule cell axons. Previous investigations in rats and humans have observed a few granule cell axon collaterals penetrating only into the inner molecular layer (Laurberg and Zimmer, 1981; Houser et al., 1990), but it is possible that in guinea pig the granule cell axon collaterals extend farther into the molecular layer. However, Timm staining of granule cell axons revealed only a few scattered collaterals crossing the granule cell layer in guinea pig (Geneser-Jensen et al., 1974, and our unpublished observations). Finally, axons containing dynorphin may be from interneurons (or other nongranule cells) scattered in the hilus and molecular layer as seen in rats (Chavkin et al., 1985), but dynorphin-containing interneurons were not seen in this study. In summary, the identity of the dynorphin-containing axons is not clear, and whether they contribute to the electrophysiological effects observed in this study is not known. However, the low relative proportion in axons compared to dendrites suggests that the dendrites may be a more significant source.

An important question concerns the functional significance of the relatively sparse distribution of dcv seen in the molecular layer. How many dynorphin-containing vesicles would be required to support the effects observed? A precise answer to this question requires additional information not presently available. We do not know (1) how much dynorphin is contained in a single dcv, (2) what fraction of the vesicle contents is released at each fusion event, (3) how many vesicles fuse with each stimulation event, or (4) exactly how far apart are the release 
sites and receptors. However, there are two lines of reasoning that suggest that the low dcv density observed may be functionally significant. The first is that the endogenous opioid effects seen in the physiological portion of this study are likely to have been produced by local release as outlined above. The only alternative source is in the subgranular plexus and is apparently too far away based on the diffusion calculations. Thus, the low number of vesicles seen is likely to be functionally significant.

The second line of reasoning is based on an estimate of the dynorphin concentration in the extracellular space following the release of the dense-core vesicle contents. If the dynorphin concentration in a dcv is $1 \mathrm{~mm}$ as estimated (Thureson-Klein and Klein 1990), the contents of a $100 \mathrm{~nm}$ dense-core vesicle (approximately 315 molecules of dynorphin B) would produce a $10 \mathrm{~nm}$ concentration in the extracellular space in a sphere of brain having a diameter of about $7.5 \mu \mathrm{m}$. To get a sense of this distance, note that the width of the tissue fields shown in the EM plates (Figs. 5-7) is $2 \mu \mathrm{m}$ or less. A concentration of $10 \mathrm{nM}$ dynorphin B should be able to occupy more than $50 \%$ of the receptors and produce a substantial effect based on the measured potency in bioassay (James et al., 1984) and binding affinity for $\kappa_{1}$ sites (Nock, 1990). Thus, the release of a single dynorphincontaining vesicle could have a substantial effect.

In this study, the numbers of dynorphin-containing dcvs observed in axons and dendrites in the molecular layer are relative, not quantitative. The counts that were done showed an average of 23 dcvs in the $50 \mu \mathrm{m}$ tract examined, which gives an estimate of about $1 \mathrm{dcv}$ per $30 \mu \mathrm{m}^{3}$. This value is likely to be a substantial underestimate of the actual vesicle density because of the very conservative criteria we used to distinguish vesicles from other labeled structurcs. Unless the vesicle was cut ncarly through its equator, it would not show the appropriate diameter, dense core, clear lumen morphology that we required. An appropriately rigorous quantitative study is in progress as true quantitative analysis of the amount of dynorphin present in each molecular layer would require different sampling methods (e.g., serial sections and randomized planes of section) (Bolender, 1991). However, the present relative comparisons between inner, middle, and outer molecular layers, and between axons and dendrites, should provide a reasonable reflection of the relative distribution (Clarke, 1989; Coggeshall, 1992) because dcv profiles did not appear to vary in size in the different regions of the molecular layer or between axons and dendrites.

Light microscopic investigation revealed a previously unreported band of dynorphin-LI at the border of the middle and outer molecular layers at the ventral pole of the hippocampus. This band was also present (although much lighter) in sections labeled with antibodies against LE, confirming a previous report of the LE-LI labeling pattern in this species (Tielen et al., 1982). The correspondence of the dynorphin-LI and LE-LI patterns may be due in part to cross-reactivity of the LE antisera, since the LE antisera used in the present study and that of Tielen et al. both recognized the LE sequence contained within dynorphin in addition to LE itself (Tielen et al., 1982; Milner et al., 1989). The source and role of this dynorphin-containing band in the molecular layer are not known.

The suggestion that dynorphin may be released from dendrites as well as axons is consistent with a growing body of evidence documenting the distinct characteristics of neuropeptidergic signaling compared to those of classical "fast" synaptic transmitters. Neuropeptide localization in and release from dendrites has previously been reported in other brain regions, including the trigeminal subnucleus caudalis (Zhu et al., 1986) and magnocellular neurons of the hypothalamus (Pow and Morris, 1989). Release of peptide-containing dcvs from dendrites was clearly shown by electron microscopic identification of exocytotic profiles at locations lacking obvious presynaptic specializations (Zhu et al., 1986; Pow and Morris, 1989; Thureson-Klein and Klein, 1990). Our results suggesting that dynorphin-containing dcvs might be released from dendrites at sites lacking presynaptic densities are consistent with these previous studies.

Transmitters released from dcvs also differ from those released from small clear vesicles in the relationship between the release site and site of action. Neuropeptides have been shown to have effects across distances many times greater than the synaptic cleft (Thureson-Klein and Klein, 1990). Similarly, the requirement for high-frequency stimulation to evoke hippocampal dynorphin release (previously established by Wagner et al., 1991 ) is like that described in other neuropeptide systems, where neuropeptide release requires much more intense stimulation than classical synaptic transmitters (Lundberg et al., 1981). Finally, many of the dendritic spines containing dynorphin-LI were postsynaptic to terminals forming asymmetric synapses. Because asymmetric synapses are believed to be excitatory (Peters et al., 1991), this observation suggests that dynorphin could be released from dendrites following physiological depolarization by afferent fibers. Thus, the hypothesis that dynorphin might be released from dendrites as well as axons in the molecular layer to modulate excitatory transmission is consistent with the many hormone-like qualities of neuropeptides in other systems. However, while our anatomical observations clearly document the presence of dynorphin-containing devs in the molecular layer and the physiological data suggest that dynorphin is released from a local source in the molecular layer, proof that dynorphin is released from either dendritic or axonal sites is extremely difficult and would require an extensive search for exocytotic profiles in this region.

The model suggested by our results is that dynorphin located in granule cells can be released following appropriate stimulation, whereupon it depresses further excitation of the granule cells by activation of $\kappa_{1}$ opioid receptors expressed on perforant path terminals. Additional data are clearly required to establish the validity of this hypothesis. A molecular layer source of dynorphin would serve as a retrograde inhibitory transmitter, tempering excitation under conditions of strong stimulation. Indeed, $\kappa$ opioids have been found to inhibit long-term potentiation induction (Wagner et al., 1993; Weisskopf et al., 1993), and seizures in a variety of animal models (Tortella et al., 1986). This feedback system may therefore play an important role in modulating the changes in excitability seen in epileptogenesis and in learning and memory.

\section{References}

Amaral DG (1978) A Golgi study of cell types in the hilar region of the hippocampus in the rat. J Comp Neurol 182:851-914.

Blackstad TW (1963) Ultrastructural studies on the hippocampal region. Prog Brain Res 3:122-148.

Bolender RP, Charleston J, Mottet JK, McCabe JT (1991) Quantitative morphology in the nervous system: expanding horizons. Anat Rec 231:407-415.

Chavkin C, James IF, Goldstein A (1982) Dynorphin is a specific endogenous ligand of the kappa opioid receptor. Science 215:413415 .

Chavkin C, Bakhit C, Weber E, Bloom FE (1983) Relative contents and concomitant release of prodynorphin/neoendorphin-derived peptides in rat hippocampus. Proc Natl Acad Sci USA 80:7669-7673. 
Chavkin C, Shoemaker WJ, McGinty JF, Bayon A, Bloom FE (1985) Characterization of the prodynorphin and proenkephalin systems in rat hippocampus. J Neurosci 5:808-816.

Clarke PGH (1989) How inaccurate is the Abercrombie correction factor for cell counts?/Coggeshall R.E. reply. Trends Neurosci 15: 211-212.

Coggeshall RE (1992) A consideration of neural counting methods. Trends Neurosci 15:9-13.

Derrick BE, Weinberger SB, Martinez JL (1991) Opioid receptors are involved in an NMDA receptor-independent mechanism of LTP induction at hippocampal mossy fiber-CA3 synapses. Brain Res Bull 27:219-223.

Descarries L, Soghomonian JJ, Gareis S, Doucet J, Bruno JP (1992) Ultrastructural analysis of the serotonin hyperinnervation in adult rat neostriatum following neonatal dopamine denervation with 6-hydroxydopamine. Brain Res 569:1-13.

Gannon RL, Terrian DM (1991) U50-488H inhibits dynorphin and glutamate release from guinea pig hippocampal mossy fiber terminals. Brain Res 548:242-247.

Geneser-Jensen FA, Huag F-MS, Danscher G (1974) Distribution of heavy metals in the hippocampal region of the guinea pig: a light microscope study with Timm's sulfide silver method. Z Zellforsch 147:441-478.

I Iille B (1992) Ionic channels of excitable membranes, 2d ed, pp 263264. Sunderland, MA: Sinauer.

Hjorth-Simonsen A (1972) Projection of the lateral part of the entorhinal area to the hippocampus and fascia dentata. J Comp Neurol 146: 219-232.

Ho WKK, Cox BM, Chavkin C, Goldstein A (1980) Opioid peptide dynorphin-(1-13): adsorptive losses and potency estimates. Neuropeptides 1:143-152.

Hong JS, McGinty JF, Lee PHK, Xie CW, Mitchell CL (1993) Relationship between hippocampal opioid peptides and seizures. Prog Neurobiol 40:507-528

Houser CR, Miyashiro JE, Schwartz BE, Walsh GO, Rich JR, DelgadoEscueta AV (1990) Altered patterns of dynorphin immunoreactivity suggest mossy fiber reorganization in human hippocampal epilepsy. J Neurosci 10:267-282.

Hsu SM, Raine L, Fanger H (1981) Use of avidin-biotin-peroxidase (ABC) in immunoperoxidase techniques: a comparison between $A B C$ and unlabeled antibody (PAP) procedures. J Histochem Cytochem 29:557-580.

James IF, Fischli W, Goldstein A (1984) Opioid receptor selectivity of dynorphin gene products. J Pharmacol Exp Ther 228:88-93.

Kanamatsu T, Obie J, Grimes L, McGinty JF, Yoshikawa K, Sabol S, Hong J-S (1986) Kainic acid alters the metabolism of met5-enkephalin and the level of dynorphin $\mathrm{A}$ in the rat hippocampus. $\mathrm{J}$ Neurosci 6:3094-3102.

Laatsch RH, Cowan WM (1966) Electron microscopic studies of the dentate gyrus of the rat. I. Normal structure with special reference to synaptic organization. J Comp Neurol 128:359-396.

Laurbcrg S, Zimmer J (1981) Lesion-induced sprouting of hippocampal mossy fiber collaterals to the fascia dentata in developing and adult rats. J Comp Neurol 200:433-459.

Lorente de No R (1934) Studies on the structure of the cerebral cortex. II. Continuation of the study on the ammonic system. J Psychol Neurol 46:113-117.

Lundberg JM, Anggard A, Fahrenkrug J, Lundgren G, Holmstedt B (1981) Corelease of VIP and acetylcholine in relation to blood flow and salivary secretion in cat submandibular salivary gland. Acta Physiol Scand 115:525-528.

McDaniel KL, Mundy WR, Tilson HA (1990) Microinjection of dynorphin into the hippocampus impairs spatial learning in rats. Pharmacol Biochem Behav 35:429-435.

McGinty JF (1993) Excitatory amino acids interact with opioid peptides to regulate neuronal excitability and gene expression in the rat hippocampal formation. In: The neurobiology of opiates (Hammer RP, ed), pp 203-221. Ann Arbor, MI: CRC.

McGinty JF, Henriksen SJ, Goldstein A, Terenius L, Bloom FE (1983) Dynorphin is contained within hippocampal mossy fibers: immunochemical alterations after kainic acid administration and colchicine-induced neurotoxicity. Proc Natl Acad Sci USA 80:589-593.

McLean S, Rothman RB, Jacobson AE, Rice KC, Herkenham M (1987) Distribution of opiate receptor subtypes and enkephalin and dynorphin immunoreactivity in the hippocampus of squirrel, guinea pig, rat and hamster. J Comp Neurol 255:497-510.
Milner TA, Veznedaroglu E (1992) Ultrastructural localization of neuropeptide Y-like immunoreactivity in the rat hippocampal formation. Hippocampus 2:107-126.

Milner TA, Pickel VM, Reis DJ (1989) Ultrastructural basis for interactions between central opioids and catecholamines. I. Rostral ventrolateral medulla. J Neurosci 9:2114-2130.

Morris BJ, Feasy KJ, ten Bruggencate G, Herz A, Holt V (1988) Electrical stimulation in vivo increases the expression of proenkephalin mRNA and decreases the expression of prodynorphin mRNA in rat hippocampal granule cells. Proc Natl Acad Sci USA 85:3226-3230.

Neal CR Jr, Newman SW (1989) Prodynorphin peptide distribution in the forebrain of the Syrian hamster and rat: a comparative study with antisera against dynorphin $\mathrm{A}$, dynorphin $\mathrm{B}$, and the $\mathrm{C}$-terminus of the prodynorphin precursor molecule. J Comp Neurol 288:353386.

Neumaier JF, Chavkin C (1989) Release of endogenous opioid peptides displaces $\left[{ }^{3} \mathrm{H}\right]$-diprenorphine binding in rat hippocampal slices. Brain Res 493:292-302.

Nicholson C (1988/1989) Issues involved in the transmission of chemical signals through the brain extracellular space. Acta Morphol Neerl Scand 26:69-80.

Nock B, Rajpara A, O'Connor LH, Cicero TJ (1988) Autoradiography of $\left[{ }^{3} \mathrm{H}\right] \mathrm{U}-69593$ binding sites in rat brain: evidence for kappa opioid receptor subtypes. Eur J Pharmacol 154:27-34.

Nock B, Giordano AL, Cicero TJ, O'Connor LH (1990) Affinity of drugs and peptides for U-69593-sensitive and -insensitive kappa opiate binding sites: the U-69593-insensitive site appears to be the beta endorphin-specific epsilon receptor. J Pharmacol Exp Ther 254:412419.

Peters A, Palay SL, deF Webster H (1991) The fine structure of the nervous system, $3 \mathrm{~d}$ ed. New York: Oxford UP.

Pickel VM, Chan J, Sesack SR (1993) Cellular substrates for interactions between dynorphin terminals and dopamine dendrites in the rat ventral tegmental area and substantia nigra. Brain Res 602:275289.

Pow DV, Morris JF (1989) Dendrites of hypothalamic magnocellular neurons release neurohypophysial peptides by exocytosis. Neuroscience 32:435-439.

Ramon y Cajal S (1991) Histologie du systeme nerveux de l'homme et des vertebres. Paris: Maloine.

Ribak CE, Seress L, Amaral DG (1985) The development, ultrastructure and synaptic connections of the mossy cells of the dentate gyrus. J Neurocytol 14:834-857.

Rice ME, Gerhardt GA, Hierl PM, Nagy G, Adams RN (1985) Diffusion coefficients of neurotransmitters and their metabolites in brain extracellular fluid space. Neuroscience 15:891-902.

Scharfman HE (1991). Dentate hilar cells with dendrites in the molecular layer have lower thresholds for synaptic activation by perforant path than granule cells. J Neurosci 11:1660-1673.

Scharfman HE, Schwartzkroin PA (1988) Electrophysiology of morphologically identified mossy cells of the dentate hilus recorded in guinca pig hippocampal slices. J Neurosci 8:3812-3821.

Scharfman HE, Kunkel DD, Schwartzkroin PA (1990) Synaptic connections of dentate granule cells and hilar neurons: results of paired intracellular recordings and intracellular horse radish peroxidase injection. Neuroscience 37:693-707.

Schenk JO, Morocco MT, Ziemba VA (1991) Interactions between argininyl moieties of neurotensin and catechol protons of dopamine. J Neurochem 57:1787-1795.

Steward $O$ (1976) Topographic organization of the projections from the entorhinal area to the hippocampal formation of the rat. J Comp Neurol 167:285-314.

Thureson-Klein AK, Klein RL (1990) Exocytosis from neuronal large dense-cored vesicles. Int Rev Cytol 121:67-126.

Tielen AM, van Leeuwen FW, Lopes da Silva FH (1982) The localization of leucine-enkephalin immunoreactivity within the guinea pig hippocampus. Exp Brain Res 48:288-295.

Tortella FC, Robles L, Mosberg HI, Holaday JW (1986) U50,488H, a highly selective kappa opioid: anticonvulsant profile in rats. J Pharmacol Exp Ther 237:49-53.

Wagner JJ, Evans CJ, Chavkin C (1991) Focal stimulation of the mossy fibers releases endogenous dynorphin that bind kappa l-opioid receptors in guinea pig hippocampus. J Neurochem 57:333-343.

Wagner JJ, Caudle RM, Chavkin C (1992) Kappa opioids decrease excitatory transmission in the dentate gyrus of the guinea pig hippocampus. J Neurosci 12:132-141. 
Wagner JJ, Terman GW, Chavkin C (1993) Endogenous dynorphins inhibit excitatory neurotransmission and block LIP induction in the hippocampus. Nature 363:451-454.

Weisskopf MG, Zalutsky RA, Nicoll RA (1993) The opioid peptide dynorphin mediates heterosynaptic depression of hippocampal mossy fibre synapses and modulates long-term potentiation. Nature 362 : 423-427.

Zhu PC, Thureson-Klein AK, KJein RL (1986) Exocytosis from large dense cored vesicles outside the active synaptic zones of terminals within the trigeminal subnucleus caudalis: a possible mechanism for neuropeptide release. Neuroscience 19:43-54.

Zukin R, Eghbali M, Olive D, Unterwald E, Tempel A (1988) Characterization and visualization of rat and guinea pig kappa opioid receptors: evidence for $\kappa_{1}$ and $\kappa_{2}$ opioid receptors. Proc Natl Acad Sci USA 85:4061-4065. 